\title{
The immune response of young turkeys to haemorrhagic enteritis virus infection at different levels and sources of methionine in the diet
}

Bartłomiej Tykałowski ${ }^{*}$ D, Marcin Śmiałek ${ }^{1}$, Andrzej Koncicki ${ }^{1}, K^{2}$ atarzyna Ognik ${ }^{2}$, Zenon Zduńczyk ${ }^{3}$ and Jan Jankowski ${ }^{4}$

\begin{abstract}
Background: Haemorrhagic enteritis (HE) of turkeys was first described in 1937 in the USA, while in Poland it was first diagnosed in 1987. Polish haemorrhagic enteritis virus (HEV) isolates are usually low pathogenic and trigger a subclinical disease. Unfortunately, even the low- pathogenic HEV strains cause severe immunosuppression leading to secondary bacterial infections and huge economic losses. The objective of this study was to evaluate if the influence of Met on HEV infected turkeys immune response can be differentiated by both its level and source. Met is one of the amino acids that not only play a nutritional role but also participate in and regulate key metabolic pathways and immune response. In our study, the birds were assigned to 4 dietary treatments which differed in Met levels ( 0.55 and $0.78 \%$ in weeks $1-4$ of age and 0.45 and $0.65 \%$ in weeks $5-8$ of age, respectively) and sources (DL-methionine (DLM) or DL-methionine hydroxy analogue (MHA)).
\end{abstract}

Results: The HEV added the percentage of $\mathrm{CD}^{+}$cells and decreased the percentage of $\mathrm{ggM}^{+}$cells in the blood, spleen and caecal tonsils (CTs) of turkeys. In addition, it increased the percentage of $\mathrm{CD}^{+} \mathrm{CD} 25^{+}$cells in blood, and interleukin-6 (IL-6) level in plasma. The higher dose of Met led to a significant decrease in the percentages of CD4 $4^{+}$, $\mathrm{CD}^{+}$and $\mathrm{CD} 4^{+} \mathrm{IL}-6^{+}$cell subpopulations in the blood of HEV-infected and uninfected turkeys and to an increase in the percentage of $\operatorname{lgM}^{+}$B cells in CTs. Turkeys administered feeds with an increased Met content displayed a decrease in plasma IL-6 levels and an increase in plasma IgA levels.

Conclusions: The results of this study indicate that HEV infection impairs the immune function in turkeys. Met content in the feed has a moderate effect on the immune response in HEV-infected turkeys. The source of this amino acid appears not be as important as its dose, because value of the analysed parameters did not differ significantly between turkeys receiving feeds with DLM or MHA. In the uninfected turkeys, the higher by $40 \%$ (than recommended by NRC) level of Met in the feeds had a positive effect on humoral immunity parameters.

Keywords: Methionine, Haemorrhagic enteritis virus, Immune response, Turkeys

\footnotetext{
* Correspondence: bartlomiej.tykalowski@uwm.edu.pl

${ }^{1}$ Department of Poultry Diseases, Faculty of Veterinary Medicine, University of

Warmia and Mazury, Oczapowskiego 13, 10-719 Olsztyn, Poland

Full list of author information is available at the end of the article
}

(c) The Author(s). 2019 Open Access This article is distributed under the terms of the Creative Commons Attribution 4.0 International License (http://creativecommons.org/licenses/by/4.0/), which permits unrestricted use, distribution, and reproduction in any medium, provided you give appropriate credit to the original author(s) and the source, provide a link to the Creative Commons license, and indicate if changes were made. The Creative Commons Public Domain Dedication waiver (http://creativecommons.org/publicdomain/zero/1.0/) applies to the data made available in this article, unless otherwise stated. 


\section{Background}

Haemorrhagic enteritis (HE) was first described in turkeys in 1937 by Pomeroy and Fenstermacher at Minnesota, USA [5]. In Poland, it was first diagnosed in 1987 [16]. Haemorrhagic enteritis virus (HEV) belongs to the family Adenoviridae, genus Siadenovirus. Under field conditions, susceptible to HEV infection are mainly turkeys over 4-6 weeks of life, whereas disease develops most often in 7-9 week old birds. $\mathrm{HEV}$ infection is usually asymptomatic. It may, however, proceed with depression, sanguineous excreta, and mortality rate approximating $80 \%$ only in the case of infection with highly pathogenic strains $[5,16,40]$. The Polish HEV isolates are usually low-pathogenic and induce subclinical infections, but severely impair the humoral and cellular reactivity of the immune system. At the acute stage of the disease, the percentage of B lymphocytes decreases significantly in blood and many immune organs, and the balance between percentage of $\mathrm{CD}^{+}$and $\mathrm{CD}^{+} \mathrm{T}$ lymphocytes is upset [40]. HEV has been shown to infect macrophages and reduce their functional capabilities. HEV-infected macrophages may undergo necrosis and apoptosis [28]. This may enhance the susceptibility to bacterial (usually E. coli and Ornithobacterium rhinotracheale (ORT)) and other viral infections in HEV-infected turkeys [5, 16, 17, 27].. An increased mortality rate due to superinfections with $E$. coli bacteria is usually observed between week 2 and 4 of life after infection with a low-pathogenic $\mathrm{HE}$ virus and may range from 2.5 to $6.5 \%$ weekly [24]. Considering the frequent exposure of turkeys to HEV infections and, consequently, their suppressed immunity, any actions aimed at aiding defence mechanisms in the course of the infection should be deemed highly desirable and valuable. One of the means to improve the health status of turkeys in commercial production is to supplement their feed mixtures with substances exhibiting immunostimulating effects. This is expected to alleviate negative outcomes of HEV and improve the birds health status and resultantly (by decreasing amounts of antibiotics used) to improve turkey production effectiveness and quality of poultry products. The substances with proved, positive impact on the immune system of poultry and their body weight gains include, i.a., vitamins, probiotics, essential oils, herbs, nucleotides, and amino acids $[4,18,19]$.

Methionine (Met) is the first limiting amino acid in feeds of poultry because the Met content of natural feed ingredients is generally low $(0.3-0.4 \%)$, below the requirements of fast-growing chickens and turkeys [12, 29]. Dietary Met content should be higher particularly in the first month of rearing, at $0.55 \%$ or even $0.70 \%$, according to the recommendations of NRC [23] and British United Turkeys [2], respectively. Therefore, commercial feeds are usually supplemented with feed-grade Met, i.e. DLmethionine (DLM) or DL-methionine hydroxy analogue (MHA) [43]. Chemically, MHA is not an amino acid but a metabolic precursor of DLM and a very effective source of supplemental Met [7, 41]. Some studies have revealed MHA to be more effective in improving the antioxidant status of chickens and turkeys than DLM [25, 38, 42].

The results of recent research indicate that Met is one of the amino acids that not only play a nutritional role but also participate in and regulate key metabolic pathways $[1,11,22]$ including those related to the immune system function $[12,13,19]$. One of the mechanisms proposed to explain Met interference in the immune system is the proliferation of $\mathrm{T}$ cells that are sensitive to intracellular variations in glutathione and cysteine levels, i.e. compounds which also participate in Met metabolism $[8,15]$. The findings of other authors indicate that dietary Met can be a major contributor to the synthesis of immune system proteins, including antibodies such as IgA [44]. IgA is a major immunoglobulin synthesized locally and secreted onto the surface of mucous membranes of respiratory airways, gastrointestinal tract, reproductive system, and many other sites. It represents the main element of mucosal immune system. In blood serum, it circulates in the form of monomers in secretions with a dimer, a trimer or a tetramer. Mucosal IgA possesses a secretory component (SC) which promotes its adhesion to epithelial surface and provides protection from proteolytic degradation within cells [10].

Experimental evidence $[3,37]$ has shown that humoral stimulation and cellular immune responses were enhanced in broiler chickens administered feeds supplemented with Met in excess of NRC dietary recommendations [23]. In a study by Jankowski et al. [14], an increase in plasma IL-6 levels was noted in turkeys administered feeds with a higher Met content. In other experiment on young turkeys, the higher dietary Met content elevated IgA concentration and decreased IL-6 plasma level [45]. IL-6 is a multifunctional cytokine that plays a major role in regulating immune responses, acute phase reactions and haematopoiesis. It is a pro-inflammatory cytokine in both birds and mammals and is produced early after infection as part of the induced innate immune response. IL-6 plays a pivotal role during the transition from innate to acquired immunity, and is also involved in the regulation of metabolic, regenerative, and neural processes. This cytokine is produced by many different cell types (monocytes, macrophages, lymphocytes, fibroblasts, endothelial cells and chondrocytes) and acts on $\mathrm{T}$ cells, B cells, hepatocytes, haematopoietic progenitor cells and cells of the central nervous system $[30,31]$. In addition, IL-6 plays a key role in the development of inflammatory lesions in intestinal mucosa of HEV-infected turkeys [27].

The available literature provides no information on the effects of Met on the immune system functioning in turkeys infected with a pathogen with a strong immunosuppressive 
activity. One of the objectives of this study was to evaluate if the influence of Met on the immune system functioning can be differentiated by both its level and source. Additionally, we have compared the immune responses of healthy and HEV - infected turkeys, administered feeds (1-8 weeks of age) containing two sources of Met (DLM and MHA) at two inclusion levels: recommended by NRC [23] $\left(\mathrm{DLM}_{\mathrm{L}}\right.$ and $\mathrm{MHA}_{\mathrm{L}}$ groups) and approximately $40 \%$ higher than that recommended by NRC (DLM ${ }_{H}$ and $\mathrm{MHA}_{\mathrm{H}}$ groups).

\section{Results}

The average body weight (BW) of 56-day-old uninfected and HEV-infected turkeys ranged from 3.94 to $4.06 \mathrm{~kg}$, and from 3.87 to $4.02 \mathrm{~kg}$, respectively. No significant differences in BW were found between HEV-infected and uninfected turkeys administered feeds supplemented with DLM or MHA. From the day of experimental infection (42 days of age) until the end of the experiment (56 days of age), no mortality was recorded in the infected and uninfected groups.

Tables 1, 2 and 3 show the percentages of $\mathrm{CD}_{4}^{+}$, $\mathrm{CD} 4^{+} \mathrm{CD} 25^{+}, \mathrm{CD}^{+}, \mathrm{CD} 4^{+} \mathrm{CD} 8^{+} \mathrm{T}$ cell subpopulations and $\operatorname{IgM}^{+} \mathrm{B}$ cell subpopulation within the mononuclear cells isolated from the blood, spleen and caecal tonsils (CTs) of 47-day-old uninfected (0) and HEV- infected (HE) turkeys from groups $\mathrm{DLM}_{\mathrm{L}}, \mathrm{MHA}_{\mathrm{L}}, \mathrm{DLM}_{\mathrm{H}}$ and $\mathrm{MHA}_{\mathrm{H}}$. The percentages of the analysed $\mathrm{T}$ cell and $\mathrm{B}$ cell subpopulations in the blood (Table 1), spleen (Table 2) and CTs (Table 3) of turkeys were most influenced by HEV infection, followed by dietary Met levels (which exerted a weaker effect on the analysed parameters) and Met sources (which exerted a minor effect). In the acute phase of infection (first 5 days post inoculation (p.i.)), the HEV-infected turkeys displayed a significant increase in the percentage of $\mathrm{CD} 4^{+}$cells and a decrease in the percentage of $\operatorname{IgM}^{+} \mathrm{B}$ cells in blood (both $P<$ $0.001)$, spleen (both $\mathrm{P}<0.001)$ and $\mathrm{CTs}(P=0.005$ and $\mathrm{P}<0.001$, respectively), compared with the uninfected birds. The higher dose of Met, regardless of its source, led to a significant decrease in the percentages of $\mathrm{CD} 4^{+}$ cell $(P=0.009)$ and $\mathrm{CD}^{+}$cell $(P=0.027)$ subpopulations in the blood of HEV-infected and uninfected turkeys (Table 1), and an increase in the percentage of $\operatorname{IgM}^{+} \mathrm{B}$ cells $(P=0.015)$ in CTs (Table 3$)$.

Both the HEV experimental infection and increased dietary Met content contributed to a significant $(P<$ 0.001 ) decrease in the blood percentage of $\mathrm{CD} 4^{+}$cells, synthesizing IL-6 in response to mitogenic stimulation under in vitro conditions. The HEV infection had a similar effect on IL- 6 synthesis by $\mathrm{CD}^{+}$cells isolated from the spleen and CTs of turkeys (Table 4).

A significant $(P<0.001)$ increase in plasma IL-6 concentrations was noted in the HEV-infected turkeys, compared
Table 1 Percentages of peripheral blood T cell and B cell subpopulations in turkeys administered feeds with different Met sources and content $(n=7)$

\begin{tabular}{|c|c|c|c|c|c|}
\hline & $\mathrm{CD}^{+}$ & $\mathrm{CD}^{+}{ }^{+} \mathrm{CD} 25^{+}$ & $\mathrm{CD}^{+}$ & $\mathrm{CD}^{+} \mathrm{CD}^{+}$ & $\operatorname{lgM}^{+}$ \\
\hline \multicolumn{6}{|l|}{ Group ${ }^{1}$} \\
\hline $0-D L M_{L}$ & 13.8 & 0.39 & 1.98 & 0.35 & 8.43 \\
\hline $0-M H A_{L}$ & 14.8 & 0.39 & 2.08 & 0.39 & 8.24 \\
\hline $0-D L M_{H}$ & 11.7 & 0.37 & 1.49 & 0.30 & 7.66 \\
\hline $0-\mathrm{MHA}_{H}$ & 11.2 & 0.38 & 1.86 & 0.33 & 9.22 \\
\hline $\mathrm{HE}-\mathrm{DLM} \mathrm{L}$ & 29.1 & 0.46 & 2.87 & 0.53 & 5.90 \\
\hline $\mathrm{HE}-\mathrm{MHA} \mathrm{A}_{\mathrm{L}}$ & 25.3 & 0.46 & 1.60 & 0.50 & 5.77 \\
\hline HE-DLM ${ }_{H}$ & 21.6 & 0.42 & 2.24 & 0.51 & 5.67 \\
\hline $\mathrm{HE}-\mathrm{MHA} \mathrm{A}_{\mathrm{H}}$ & 19.8 & 0.46 & 1.75 & 0.50 & 6.31 \\
\hline \multicolumn{6}{|l|}{ Infection } \\
\hline 0 & 12.87 & 0.382 & 1.854 & 0.341 & 8.39 \\
\hline $\mathrm{HE}$ & 23.96 & 0.450 & 2.116 & 0.511 & 5.91 \\
\hline \multicolumn{6}{|l|}{ Met dosage } \\
\hline Low & 20.76 & 0.423 & 2.295 & 0.445 & 7.06 \\
\hline High & 16.07 & 0.409 & 1.675 & 0.407 & 7.24 \\
\hline \multicolumn{6}{|l|}{ Met source } \\
\hline DLM & 19.06 & 0.410 & 1.987 & 0.419 & 6.94 \\
\hline MHA & 17.77 & 0.422 & 1.983 & 0.433 & 7.36 \\
\hline $\mathrm{SEM}^{2}$ & 1.250 & 0.013 & 0.138 & 0.022 & 0.255 \\
\hline \multicolumn{6}{|l|}{$p$ - values } \\
\hline Infection & $<0.001$ & 0.011 & 0.333 & $<0.001$ & $<0.001$ \\
\hline Dose & 0.009 & 0.581 & 0.027 & 0.319 & 0.572 \\
\hline Source & 0.450 & 0.636 & 0.987 & 0.712 & 0.197 \\
\hline Interaction & $n d^{3}$ & nd & nd & nd & nd \\
\hline
\end{tabular}

${ }^{1}$ Feeds administered to uninfected $(0)$ and infected (HE) turkeys in weeks 1-4 and 5-8, contained DLM and the equivalent amount of MHA at two levels: low ${ }_{L}()-0.55,0.45$, and high $\left(_{H}\right)-0.78,0.65$, respectively [\% as fed] ${ }^{2}$ SEM- standard error of the mean

${ }^{3}$ nd - not detected: no significant infection $\mathrm{x}$ dose, infection $\mathrm{x}$ source, dose $\mathrm{x}$ source or infection $\mathrm{x}$ dose $\mathrm{x}$ source interactions

with the uninfected birds. Plasma IL-6 levels were lower in turkeys fed with the higher MHA dose (Table 5).

Anti-ND antibody titres were not significantly affected by dietary Met sources or levels, but they were significantly $(P=0.004)$ lower in the HEV-infected turkeys than in the uninfected birds (Table 6). Average vaccineinduced anti-ORT antibody titres were significantly $(\mathrm{P}<$ 0.001 ) higher at 56 days of age in the HEV-infected turkeys than in the uninfected birds.

\section{Discussion}

No deterioration of production performance was observed in our study for the HEV-infected turkeys administered feeds supplemented with DLM or MHA. The Polish isolate of HEV used in the experiment is characterised by low pathogenicity and, in the absence of 
Table 2 Percentages of T cell and B cell subpopulations in the spleen in turkeys administered feeds with different Met sources and content $(n=7)$

\begin{tabular}{|c|c|c|c|c|c|}
\hline & $\mathrm{CD}^{+}$ & $\mathrm{CD}^{+} \mathrm{CD}_{25}{ }^{+}$ & $\mathrm{CD} 8^{+}$ & $\mathrm{CD}^{+} \mathrm{CD}^{+}$ & $\operatorname{lgM}^{+}$ \\
\hline \multicolumn{6}{|l|}{ Group $^{1}$} \\
\hline $0-D\left\llcorner M_{L}\right.$ & 33.3 & 1.55 & 37.9 & 2.00 & 18.2 \\
\hline $0-M H A_{L}$ & 35.3 & 1.65 & 33.5 & 2.46 & 18.6 \\
\hline $0-D L M_{H}$ & 33.1 & 1.73 & 36.4 & 2.12 & 20.8 \\
\hline $0-\mathrm{MHA}_{H}$ & 29.3 & 1.75 & 37.3 & 2.15 & 21.8 \\
\hline HE-DLM & 51.4 & 1.67 & 25.0 & 1.88 & 15.8 \\
\hline HE-MHA $A_{L}$ & 55.9 & 1.61 & 24.7 & 2.09 & 14.9 \\
\hline $\mathrm{HE}-\mathrm{DLM} \mathrm{M}_{\mathrm{H}}$ & 53.8 & 1.83 & 19.1 & 2.24 & 16.7 \\
\hline $\mathrm{HE}-\mathrm{MHA} \mathrm{A}_{\mathrm{H}}$ & 50.4 & 1.76 & 21.4 & 2.12 & 14.7 \\
\hline \multicolumn{6}{|l|}{ Infection } \\
\hline 0 & 32.73 & 1.669 & 36.28 & 2.184 & 19.72 \\
\hline $\mathrm{HE}$ & 52.85 & 1.716 & 22.56 & 2.083 & 15.53 \\
\hline \multicolumn{6}{|l|}{ Met dosage } \\
\hline Low & 43.95 & 1.620 & 30.29 & 2.108 & 16.89 \\
\hline High & 41.63 & 1.765 & 28.55 & 2.159 & 18.36 \\
\hline \multicolumn{6}{|l|}{ Met source } \\
\hline DLM & 42.89 & 1.694 & 29.60 & 2.063 & 17.89 \\
\hline MHA & 42.70 & 1.691 & 29.24 & 2.204 & 17.36 \\
\hline $\mathrm{SEM}^{2}$ & 1.860 & 0.046 & 1.477 & 0.109 & 0.558 \\
\hline \multicolumn{6}{|l|}{$p$ - values } \\
\hline Infection & $<0.001$ & 0.629 & $<0.001$ & 0.670 & $<0.001$ \\
\hline Dose & 0.233 & 0.145 & 0.401 & 0.829 & 0.117 \\
\hline Source & 0.921 & 0.972 & 0.864 & 0.552 & 0.568 \\
\hline Interactions & $n d^{3}$ & nd & nd & nd & nd \\
\hline
\end{tabular}

${ }^{1}$ Feeds administered to uninfected (0) and infected (HE) turkeys in weeks 1-4 and 5-8, contained DLM and the equivalent amount of MHA at two levels: low ${ }_{(L)}-0.55,0.45$, and high $\left.{ }_{H}\right)-0.78,0.65$, respectively [\% as fed] ${ }^{2} \mathrm{SEM}$ - standard error of the mean

${ }^{3}$ nd - not detected: no significant infection $\mathrm{x}$ dose, infection $\mathrm{x}$ source, dose $\mathrm{x}$ source or infection $\mathrm{x}$ dose $\mathrm{x}$ source interactions

secondary bacterial infections, it does not increase birds mortality or significant changes in BW. However, even low-virulence strains that cause subclinical infection can result in immunosuppression $[16,17,40]$.

Results of our study indicate that the HEV infection strongly influences the immune system of turkeys, which leads to a significant increase in the percentage of $\mathrm{CD}^{+}$cells and a decrease in the percentage of $\mathrm{IgM}^{+} \mathrm{B}$ cells in their blood, spleen, and CTs. Present results corroborate previous findings $[17,36]$. There is a scarcity of studies investigating the effect of HEV on the percentages of the analysed cell subsets in CTs. Regulatory $\mathrm{T}$ cells $\left(\mathrm{T}_{\text {reg }}\right)$, a subset of $\mathrm{T}$ cells identified by the co-expression of CD4 and CD25, suppress immune responses to self-antigens and prevent autoimmune diseases. There is emerging evidence to
Table 3 Percentages of T cell and B cell subpopulations in the CTs in turkeys administered feeds with different Met sources and content $(n=7)$

\begin{tabular}{|c|c|c|c|c|c|}
\hline & $\mathrm{CD}^{+}$ & $\mathrm{CD}^{+}{ }^{+} \mathrm{CD} 25^{+}$ & $\mathrm{CD}^{+}$ & $\mathrm{CD}^{+} \mathrm{CD}^{+}$ & $\operatorname{lgM}^{+}$ \\
\hline \multicolumn{6}{|l|}{ Group $^{1}$} \\
\hline $0-D L M_{L}$ & 51.6 & 1.50 & 14.2 & 2.33 & 15.6 \\
\hline $0-M H A_{L}$ & 53.9 & 1.61 & 14.0 & 1.83 & 14.5 \\
\hline $0-D\left\llcorner M_{H}\right.$ & 51.3 & 1.51 & 14.7 & 1.61 & 18.2 \\
\hline $0-\mathrm{MHA}_{H}$ & 46.8 & 1.87 & 15.1 & 1.85 & 18.1 \\
\hline HE-DLM & 55.6 & 1.44 & 15.9 & 1.77 & 11.1 \\
\hline $\mathrm{HE}-\mathrm{MHA} \mathrm{A}_{\mathrm{L}}$ & 61.3 & 1.55 & 14.6 & 2.38 & 10.9 \\
\hline HE-DLM ${ }_{H}$ & 57.0 & 1.46 & 13.4 & 3.05 & 12.5 \\
\hline $\mathrm{HE}-\mathrm{MHA} \mathrm{A}_{\mathrm{H}}$ & 54.1 & 1.64 & 15.1 & 2.23 & 12.7 \\
\hline \multicolumn{6}{|l|}{ Infection } \\
\hline 0 & 50.9 & 1.62 & 14.5 & 1.90 & 16.6 \\
\hline $\mathrm{HE}$ & 57.0 & 1.52 & 14.8 & 2.36 & 11.8 \\
\hline \multicolumn{6}{|l|}{ Met dosage } \\
\hline Low & 55.6 & 1.52 & 14.7 & 2. 08 & 13.0 \\
\hline High & 52.3 & 1.62 & 14.6 & 2.18 & 15.4 \\
\hline \multicolumn{6}{|l|}{ Met source } \\
\hline DLM & 53.9 & 1.48 & 14.6 & 2.19 & 14.3 \\
\hline MHA & 54.0 & 1.67 & 14.7 & 2.07 & 14.0 \\
\hline $\mathrm{SEM}^{2}$ & 1.12 & 0.031 & 0.458 & 0.156 & 0.603 \\
\hline \multicolumn{6}{|l|}{$p$ - values } \\
\hline Infection & 0.005 & 0.060 & 0,805 & 0.149 & $<0.001$ \\
\hline Dose & 0.110 & 0.062 & 0.895 & 0.738 & 0.015 \\
\hline Source & 0.939 & 0.001 & 0.905 & 0.704 & 0.744 \\
\hline Interactions & $n d^{3}$ & nd & nd & nd & nd \\
\hline
\end{tabular}

${ }^{1}$ Feeds administered to uninfected $(0)$ and infected (HE) turkeys in weeks 1-4 and 5-8, contained DLM and the equivalent amount of MHA at two levels: low $\left(\llcorner)-0.55,0.45\right.$, and high $\left.{ }_{H}\right)-0.78,0.65$, respectively [\% as fed] ${ }^{2} \mathrm{SEM}$ - standard error of the mean

${ }^{3}$ nd - not detected: no significant infection $\mathrm{x}$ dose, infection $\mathrm{x}$ source, dose $\mathrm{x}$ source or infection $\mathrm{x}$ dose $\mathrm{x}$ source interactions

suggest that regulatory $\mathrm{T}$ cells control immune responses to bacteria, viruses, parasites and fungi [21]. Regulatory $\mathrm{T}$ cells have been identified in several species, including humans, dogs, cats, pigs, cows, sheep, horses, chickens and turkeys $[6,32,33]$. The mechanism of the suppressive function of natural and inducible regulatory $\mathrm{T}$ cells is still debated, but in different model systems, suppressive activity has been shown to be mediated either through secretion of immunosuppressive cytokines or through cell-cell contact [21].

Many studies have shown that pathogens, in particular those that cause chronic infections or are associated with immunosuppression, induce the production of regulatory cytokines IL-10 and TGF- $\beta$ [20]. Turkey thymic CD $4^{+} \mathrm{CD} 25^{+}$ cells have approximately 158-fold higher IL-10 mRNA, 7fold higher TGF- $\beta$, 24-fold higher CTLA-4 and 11-fold 
Table 4 The percentage of $\mathrm{CD}^{+}$cells isolated from blood, spleen and CTs, synthesizing IL-6 in response to mitogenic stimulation under in vitro conditions $(n=7)$

\begin{tabular}{|c|c|c|c|}
\hline & Blood & Spleen & CTs \\
\hline \multicolumn{4}{|l|}{ Group 1} \\
\hline $0-D L M_{L}$ & 1.67 & 0.88 & 0.58 \\
\hline $0-M H A_{L}$ & 1.38 & 0.67 & 0.57 \\
\hline $0-D\left\llcorner M_{H}\right.$ & 1.09 & 0.68 & 0.62 \\
\hline $0-M H A_{H}$ & 0.84 & 0.77 & 0.58 \\
\hline $\mathrm{HE}-\mathrm{DLM} \mathrm{L}_{\mathrm{L}}$ & 0.97 & 0.38 & 0.48 \\
\hline $\mathrm{HE}-\mathrm{MHA} \mathrm{A}_{\mathrm{L}}$ & 0.52 & 0.38 & 0.44 \\
\hline HE-DLM & 0.85 & 0.32 & 0.49 \\
\hline $\mathrm{HE}-\mathrm{MHA} \mathrm{A}_{\mathrm{H}}$ & 0.40 & 0.32 & 0.43 \\
\hline \multicolumn{4}{|l|}{ Infection } \\
\hline 0 & 1.247 & 0.751 & 0.59 \\
\hline $\mathrm{HE}$ & 0.685 & 0.354 & 0.46 \\
\hline \multicolumn{4}{|l|}{ Met dosage } \\
\hline Low & 1.219 & 0.580 & 0.51 \\
\hline High & 0.713 & 0.525 & 0.53 \\
\hline \multicolumn{4}{|l|}{ Met source } \\
\hline DLM & 1.064 & 0.567 & 0.54 \\
\hline $\mathrm{MHA}$ & 0.868 & 0.538 & 0.50 \\
\hline $\mathrm{SEM}^{2}$ & 0.069 & 0.036 & 0.018 \\
\hline \multicolumn{4}{|l|}{$p$ - values } \\
\hline Infection & $<0.001$ & $<0.001$ & $<0.001$ \\
\hline Dose & $<0.001$ & 0.097 & 0.661 \\
\hline Source & 0.004 & 0.361 & 0.204 \\
\hline Interactions & $n d^{3}$ & nd & nd \\
\hline
\end{tabular}

${ }^{1}$ Feeds administered to uninfected (0) and infected (HE) turkeys in weeks 1-4 and 5-8, contained DLM and the equivalent amount of MHA at two levels low ${ }_{(L)}-0.55,0.45$, and high $\left(_{H}\right)-0.78,0.65$, respectively [\% as fed] ${ }^{2} \mathrm{SEM}$ - standard error of the mean;

${ }^{3}$ nd - not detected: no significant infection $\mathrm{x}$ dose, infection $\mathrm{x}$ source, dose $\mathrm{x}$ source or infection $\mathrm{x}$ dose $\mathrm{x}$ source interactions

higher LAG-3 mRNA amounts than thymic $\mathrm{CD} 4^{+} \mathrm{CD} 25^{-}$ cells [33].

There is a scarcity of studies investigating the role of regulatory $\mathrm{T}$ cells in the course of HEV infection in turkeys. In the current study, the percentage of $\mathrm{CD} 4{ }^{+} \mathrm{CD} 25^{+}$cells increased significantly in the blood of HEV-infected turkeys on day 5 p.i. A significant increase in the percentage of $\mathrm{CD} 4{ }^{+} \mathrm{CD} 25^{+}$cells was also noted in the CTs of the turkeys administered MHA-supplemented feeds relative to the birds fed DLM-supplemented feed mixtures. Our results and the findings of other authors $[9,28,36]$ indicate that HEV impairs immune function in infected turkeys, leading to strong immunosuppression. After exposure, HEV may replicate in B lymphocytes located in the intestines and the bursa of Fabricius, or it may travel directly to the spleen through peripheral blood infecting numerous macrophages and B cells,
Table 5 Plasma IgA and IL-6 levels in turkeys $(n=7)$

\begin{tabular}{|c|c|c|}
\hline & $\operatorname{lgA}[\mu \mathrm{g} / \mathrm{ml}]$ & IL-6 [pg/ml] \\
\hline \multicolumn{3}{|l|}{$\overline{\text { Group }^{1}}$} \\
\hline $0-D L M_{L}$ & 0.176 & $0.141^{b}$ \\
\hline $0-M H A_{L}$ & 0.096 & $0.161^{b}$ \\
\hline $0-D_{L} M_{H}$ & 0.159 & $0.121^{b c}$ \\
\hline $0-M H A_{H}$ & 0.278 & $0.118^{\mathrm{bc}}$ \\
\hline HE-DLM & 0.178 & $0.385^{\mathrm{a}}$ \\
\hline$H E-M H A_{L}$ & 0.086 & $0.101^{b c}$ \\
\hline HE-DLM $M_{H}$ & 0.101 & $0.201^{b}$ \\
\hline $\mathrm{HE}-\mathrm{MHA} \mathrm{A}_{H}$ & 0.103 & $0.070^{c}$ \\
\hline \multicolumn{3}{|l|}{ Infection } \\
\hline 0 & 0.177 & 0.135 \\
\hline $\mathrm{HE}$ & 0.117 & 0.189 \\
\hline \multicolumn{3}{|l|}{ Met dosage } \\
\hline Low & 0.134 & 0.197 \\
\hline High & 0.160 & 0.127 \\
\hline \multicolumn{3}{|l|}{ Met source } \\
\hline DLM & 0.153 & 0.212 \\
\hline MHA & 0.141 & 0.113 \\
\hline $\mathrm{SEM}^{2}$ & 0.012 & 0.017 \\
\hline \multicolumn{3}{|l|}{$p$ - values } \\
\hline Infection & $<0.001$ & $<0.001$ \\
\hline Dose & 0.068 & $<0.001$ \\
\hline Source & 0.414 & $<0.001$ \\
\hline Interactions & $n d^{3}$ & $d^{4}$ \\
\hline
\end{tabular}

${ }^{1}$ Feeds administered to uninfected (0) and infected (HE) turkeys in weeks 1-4 and 5-8, contained DLM and the equivalent amount of MHA at two levels low ${ }_{(L)}-0.55,0.45$, and high $\left(_{H}\right)-0.78,0.65$, respectively [\% as fed]

${ }^{2} \mathrm{SEM}$ - standard error of the mean

${ }^{3}$ nd - not detected: no significant infection $\mathrm{x}$ dose, infection $\mathrm{x}$ source, dose $\mathrm{x}$ source or infection $x$ dose $x$ source interactions

${ }^{4} \mathrm{~d}$ - detected: Significant interactions between the experimental factors; higher dose of DLM and both doses of MHA decreased plasma IL-6 levels in HEV-infected turkeys

a-c values differ significantly

and replicate efficiently [35]. The infection of target cells in the spleen leads to the influx of macrophages and $\mathrm{CD} 4^{+} \mathrm{T}$ cells in the white pulp, resulting in hyperplasia. The activation of macrophages by HEV leads to the production of cytokines such as IL-6, tumour necrosis factor (TNF) and interferon (IFN) type I and II [28]. In the acute phase of the disease, the depletion of $\operatorname{IgM}^{+} \mathrm{B}$ cells occurs in the blood and spleen of birds $[17,36]$. Virus-induced cell necrosis and apoptosis may compromise the antigen-presenting function and possibly other functions of macrophages and B cells. In the present study, the higher dietary Met level induced a lesser decrease in the percentage of $\operatorname{IgM}^{+} \mathrm{B}$ cells in HEVinfected turkeys, particularly in their CTs.

Results of our study demonstrate that the higher supplementation levels of Met, used in the form of DLM 
Table 6 Vaccine-induced antibody titres in the blood serum of 56-day-old turkeys $(n=23)$

\begin{tabular}{|c|c|c|}
\hline & ORT & NDV \\
\hline \multicolumn{3}{|l|}{ Group $^{1}$} \\
\hline 0-DLM & $12879^{b}$ & 236 \\
\hline $0-M H A_{L}$ & $11116^{\mathrm{b}}$ & 768 \\
\hline $0-D L M_{H}$ & $15022^{b}$ & 443 \\
\hline $0-M H A_{H}$ & $14571^{b}$ & 376 \\
\hline $\mathrm{HE}-\mathrm{DLM} \mathrm{L}_{\mathrm{L}}$ & $23072^{\mathrm{a}}$ & 69 \\
\hline HE-MHA $A_{L}$ & $17976^{a b}$ & 150 \\
\hline HE-DLM $M_{H}$ & $15849^{b}$ & 117 \\
\hline $\mathrm{HE}-\mathrm{MHA} \mathrm{A}_{H}$ & $19120^{b}$ & 139 \\
\hline \multicolumn{3}{|l|}{ Infection } \\
\hline 0 & 13,397 & 441 \\
\hline $\mathrm{HE}$ & 19,004 & 119 \\
\hline \multicolumn{3}{|l|}{ Met dosage } \\
\hline Low & 14,581 & 358 \\
\hline High & 15,611 & 324 \\
\hline \multicolumn{3}{|l|}{ Met source } \\
\hline DLM & 15,620 & 265 \\
\hline $\mathrm{MHA}$ & 14,572 & 421 \\
\hline $\mathrm{SEM}^{2}$ & 687 & 185 \\
\hline \multicolumn{3}{|l|}{$p$ - values } \\
\hline Infection & $<0.001$ & 0.004 \\
\hline Dose & 0.932 & 0.746 \\
\hline Source & 0.473 & 0.215 \\
\hline Interactions & $0.039^{3}$ & $\mathrm{nd}^{4}$ \\
\hline
\end{tabular}

${ }^{1}$ Feeds administered to uninfected (0) and infected (HE) turkeys in weeks 1-4 and 5-8, contained DLM and the equivalent amount of MHA at two levels: low (L) $-0.55,0.45$, and high $\left.{ }_{H}\right)-0.78,0.65$, respectively [\% as fed]

${ }^{2}$ SEM- standard error of the mean

${ }^{3}$ Significant interactions between the experimental factors; HEV added antiORT antibody titres, particularly in turkeys fed feeds with lower DLM content ${ }^{4}$ nd - not detected: no significant infection $\mathrm{x}$ dose, infection $\mathrm{x}$ source, dose $\mathrm{x}$ source or infection $\mathrm{x}$ dose $\mathrm{x}$ source interactions

and MHA, reduced the blood level of IL-6 in both the HEV-infected and uninfected turkeys. IL-6 plays a major role in regulating immune responses and acute phase reactions [30,31]. It is a pro-inflammatory cytokine and is produced early (2-3 days p.i) after HEV infection as part of the induced innate immune response. It appears that in our study, cells other than $\mathrm{CD}^{+}$lymphocytes, activated by HEV, secreted IL- 6 and contributed to an increase in the plasma concentrations of this interleukin. Earlier investigations conducted by other authors have demonstrated high IL-6 and TNF level at the peak of the acute phase in HEV-infected turkeys. Cytokines may play a protective as well as a destructive role. While a massive release of proinflammatory cytokines may lead to systemic shock associated with haemorrhagic enteritis and death [27].
Immunosuppression induced by HEV infection may impair post-vaccination immunity after the administration of live vaccines, which was observed in the current study in turkeys vaccinated against ND. Usually, once-vaccinated turkeys do not develop high levels of serum antibodies as detected in the ELISA test. Our findings correspond to the observations of other authors [9]. In turkeys that had been vaccinated twice against ORT with an inactivated vaccine, vaccine-induced antibody titres were significantly higher in the serum of 56-day-old birds administered feeds with increased Met content, which corroborates the findings of Kubińska et al. [19]. Average plasma IgA levels were also higher in turkeys receiving higher Met concentrations. Our findings are consistent with the results of other studies which show that dietary Met can be a major contributor to the synthesis of immune system proteins, including IgA $[12,44]$.

Interesting results of serological analyses were obtained in the HEV-infected turkeys that were revaccinated against ORT at 49 days of age ( 7 days p.i.). Over that period, the number of HEV Hexon gene copies, determined in the spleen by qPCR, is higher than 3 and 14 days p.i. (Tykałowski B, unpublished data). Despite this fact, average vaccine-induced anti-ORT antibody titres were higher at 56 days of age in the HEV-infected turkeys than in the uninfected birds. The increase in anti-ORT antibody titres could have resulted from the activation of the immune system of the HEV-infected turkeys. Similar results were reported by Rautenschlein and Sharma [26]. In the cited study, 5- to 6-week-old turkeys were simultaneously vaccinated with attenuated NDV-B1 $E L D_{50}=10^{5}$ /bird intraocular) and cell culture-adapted HEV (HEVp30) at $\operatorname{TCID}_{50}=10^{4} /$ bird per os. At 14 days post vaccination, the anti-NDV antibody response was significantly enhanced $(P<0.05)$ in HEVp30 + NDV-vaccinated turkeys in comparison with the single-inoculated birds. At 21 days post vaccination, anti-HEV and anti-NDV antibody responses were similar in all vaccinated groups. However, the combination of HEVp30 and NDV-B1 enhanced the rate of apoptosis in splenic cells. However, the mechanism of the enhancement of anti-NDV antibodies remains unknown.

\section{Conclusions}

The results of this study indicate that HEV infection impairs immune function in turkeys. Depending on its content in the feed, methionine used in our study moderately affected the immune response of HEVinfected turkeys by alleviating infection outcomes. The source of this exogenous amino acid is not as important as its dose is, because values of the analysed parameters did not differ significantly between turkeys administered feeds with DLM or MHA. In 
the uninfected turkeys, the higher by $40 \%$ level of methionine in the feed (than that recommended by NRC) had a positive effect on humoral immunity parameters, causing an increase both in the percentage of B lymphocytes in blood, spleen and CTs, and in plasma level of IgA.

\section{Methods}

\section{Birds, management and feeds}

The study was conducted on 240 day-old female Hybrid Converter turkey poults purchased from a local hatchery (Grelavi S.A., Ketrzyn, Poland) and kept in isolated pens in the Pavilion of Avian Experimental Infections of the Department of Avian Diseases of the University of Warmia and Mazury in Olsztyn. The facility conforms to the relevant biosafety level (BSL-3). The birds were randomly assigned to 4 dietary treatments (60 birds per treatment). Each treatment was further divided into two groups (kept in 2 separate isolated pens, 30 birds per group). The total number of birds in each group was adapted to the size of experimental boxes. The dietary treatments differed in the level (low - "L" or high - “ $\mathrm{H}$ ") and the source (DLM or MHA) of Met in feed. In each dietary treatment $\left(\mathrm{DLM}_{\mathrm{L}}, \mathrm{MHA}_{\mathrm{L}}, \mathrm{DLM}_{\mathrm{H}}\right.$ and $\mathrm{MHA}_{\mathrm{H}}$, respectively), one group was inoculated with HEV and the other group served as uninfected control. The experiment layout is presented in Table 7 .

The temperature and lighting programs were consistent with the recommendations of Hendrix Genetics Ltd. (Canada) for Hybrid Converter turkeys. The birds had free access to feed and water. All experimental procedures were consistent with permission No. 45/2013 of the Local Ethics Committee for Animal Experiments in Olsztyn (Poland). NRC [23] recommendations were adopted as the low dietary levels of DLM (Evonik Industries, Krefeld, Germany) and MHA (calcium salt of 2hydroxy-4-(methyl) butanoic acid, Novus International, Inc., USA). The dietary Met content increased by $40 \%$ relative to NRC [23] recommendations was regarded as the high level which contributed to achieving good turkey performance in previous experiments $[13,18,19]$.

The nutritional value of basal feeds prepared in two successive 4-week periods (Table 8) was calculated according to the Polish Feedstuff Analysis Tables [34]. The analytically verified total Met content of experimental feeds, i.e. the lower and higher dietary levels of Met (including the equivalent amount of MHA), was 0.55 and $0.78 \%$ in weeks $1-4$ of age, respectively, and 0.45 and $0.65 \%$ in weeks $5-8$ of age, respectively.

\section{Vaccination}

Experimental turkeys fell under a standard vaccination program, practiced at commercial farms in Poland. At 10 days of age, all 240 turkeys were vaccinated against Newcastle disease virus (NDV). The vaccine (Nobilis ${ }^{\circ} \mathrm{ND}$, Clone 30, MSD, USA) was administered in a dose recommended by the producer with a dropper at one drop $(0.05$ $\mathrm{ml}$ ) per bird into one eye. At 28 and 49 days of age, turkeys were vaccinated against ORT by subcutaneous administration of $0.5 \mathrm{ml}$ of Ornitin vaccine (ABIC, Poland).

Table 7 Experiment layout

\begin{tabular}{|c|c|c|c|c|c|c|c|}
\hline \multirow{2}{*}{$\begin{array}{l}\text { Dietary } \\
\text { treatment }{ }^{1} \\
(n=60)\end{array}$} & \multirow{2}{*}{$\begin{array}{l}\text { Group } \\
(n= \\
30)\end{array}$} & \multicolumn{6}{|l|}{ Days of age } \\
\hline & & 10 & 28 & $\begin{array}{l}42 \\
\text { (experimental } \\
\text { infection) }\end{array}$ & 47 & 49 & 56 \\
\hline \multirow[t]{2}{*}{$\overline{D_{L} M_{L}}$} & $\begin{array}{l}0- \\
D L M L\end{array}$ & $\begin{array}{l}\text { Vaccination } \\
\text { against ND }\end{array}$ & $\begin{array}{l}\text { Vaccination } \\
\text { against ORT }\end{array}$ & $0^{2}$ & \multirow{8}{*}{$\begin{array}{l}\text { Collection of samples of } \\
\text { blood and organs from } 7 \\
\text { turkeys per group for immunological } \\
\left(\mathrm{CD} 4^{+}, \mathrm{CD} 8^{+}, \mathrm{CD} 4^{+} \mathrm{CD} 8^{+}, \mathrm{CD} 4^{+}\right. \\
\left.\mathrm{CD} 25^{+}, \mathrm{CD} 4^{+} \mathrm{IL}-6^{+}, \mathrm{IgM}^{+}\right) \text {and } \\
\text { biochemical analyses (IgA, IL-6) }\end{array}$} & \multirow[t]{8}{*}{$\begin{array}{l}\text { Vaccination } \\
\text { against ORT }\end{array}$} & \multirow{8}{*}{$\begin{array}{l}\text { Collection of blood } \\
\text { samples from } 23 \\
\text { turkeys per group } \\
\text { for serological analyses } \\
\text { (antibody against } \\
\text { ORT and NDV) }\end{array}$} \\
\hline & $\begin{array}{l}\text { HE- } \\
\text { DLM }\end{array}$ & & & $+{ }^{3}$ & & & \\
\hline \multirow[t]{2}{*}{$M H A_{L}$} & $\begin{array}{l}0- \\
M H A_{L}\end{array}$ & & & 0 & & & \\
\hline & $\begin{array}{l}\mathrm{HE}- \\
\mathrm{MHA}_{\mathrm{L}}\end{array}$ & & & + & & & \\
\hline \multirow[t]{2}{*}{$\mathrm{DLM}_{\mathrm{H}}$} & $\begin{array}{l}0- \\
\mathrm{DLM}_{H}\end{array}$ & & & 0 & & & \\
\hline & $\begin{array}{l}\mathrm{HE}- \\
\mathrm{DLM}_{\mathrm{H}}\end{array}$ & & & + & & & \\
\hline \multirow[t]{2}{*}{$\mathrm{MHA}_{H}$} & $\begin{array}{l}0- \\
\mathrm{MHA}_{H}\end{array}$ & & & 0 & & & \\
\hline & $\begin{array}{l}\mathrm{HE}- \\
\mathrm{MHA}_{H}\end{array}$ & & & + & & & \\
\hline
\end{tabular}

${ }^{1}$ Feeds administered to turkeys in weeks $1-4$ and 5-8, contained DLM and the equivalent amount of MHA at two levels: low $(\llcorner)-0.55,0.45$, and high $(\mathrm{H})-0.78$, 0.65 , respectively [\% as fed

${ }^{2} 0$ - uninfected turkeys (received $1 \mathrm{ml}$ of sterile PBS into the crop)

${ }^{3}+-$ turkeys inoculated with $1 \mathrm{ml}$ of a suspension containing $\mathrm{HEV}$ at a dose of $10^{4,3} \mathrm{EID}_{50}$, administered into the crop 
Table 8 Composition and nutrient concentrations in basal feeds

\begin{tabular}{|c|c|c|}
\hline \multirow[t]{2}{*}{ Item } & \multicolumn{2}{|c|}{ Feeding period (weeks) } \\
\hline & $\overline{1-4}$ & $5-8$ \\
\hline \multicolumn{3}{|l|}{ Ingredients as fed [g/kg] } \\
\hline Wheat & 49.09 & 49.26 \\
\hline Soybean meal & 41.65 & 40.56 \\
\hline Soybean oil & 2.02 & 2.90 \\
\hline Fish meal & 3.00 & - \\
\hline Rapeseed meal & - & 3.00 \\
\hline Sodium sulphate & 0.15 & 0.15 \\
\hline Sodium chloride & 0.11 & 0.15 \\
\hline Limestone & 1.41 & 1.46 \\
\hline Monocalcium phosphate & 1.61 & 1.52 \\
\hline L-Lysine $\mathrm{HCl}$ & 0.38 & 0.41 \\
\hline L-Threonine & 0.08 & 0.09 \\
\hline Vitamin-mineral premix ${ }^{a}$ & 0.50 & 0.50 \\
\hline \multicolumn{3}{|l|}{ Calculated nutritional value ${ }^{\mathrm{b}}$} \\
\hline Metabolizable energy [Kcal/kg] & 2750 & 2850 \\
\hline Crude protein [\%] & 27.0 & 25.0 \\
\hline Arginine [\%] & 1.71 & 1.59 \\
\hline Lysine [\%] & 1.74 & 1.603 \\
\hline Methionine [\%] & 0.40 & 0.34 \\
\hline Methionine + cysteine [\%] & 0.84 & 0.76 \\
\hline Threonine [\%] & 1.05 & 0.98 \\
\hline $\mathrm{Ca}[\%]$ & 1.20 & 1.10 \\
\hline $\mathrm{P}[\%]$ & 0.81 & 0.74 \\
\hline Available P [\%] & 0.58 & 0.50 \\
\hline Sodium [\%] & 0.15 & 0.13 \\
\hline
\end{tabular}

${ }^{\mathrm{a}} 0.5 \%$ of the premix provided per $\mathrm{kg}$ of diet: vitamin a (all trans-retinol acetate) - 15,000 IU, vitamin $D_{3}$ (cholecalciferol) - 5000 IU, vitamin E (all-rac- - tocopheryl acetate) - $100 \mathrm{mg}$, vitamin $\mathrm{K}_{3-} 4 \mathrm{mg}$, vitamin $B_{1}-5 \mathrm{mg}$, vitamin $B_{2}$

$-15 \mathrm{mg}$, vitamin $B_{6-} 6 \mathrm{mg}$, niacin - $100 \mathrm{mg}$, biotin $-0.35 \mathrm{mg}$, pantothenic acid -

$32 \mathrm{mg}$, nicotinic acid $-100 \mathrm{mg}$, folic acid $-4 \mathrm{mg}$, choline chloride - $700 \mathrm{mg}, \mathrm{Mn}$

- 100 mg, Zn - 80 mg, Fe - 60 mg, cu - 20 mg, I - 1.5 mg, se - 0.3 mg, Ca $-1.07 \mathrm{~g}$

${ }^{b}$ Calculated according to the Polish Feedstuff Analysis Tables [34]

\section{Experimental inoculation with HEV}

At 42 days of age, turkeys from HE-DLM $\mathrm{L}_{\mathrm{L}}, \mathrm{HE}-\mathrm{MHA}_{\mathrm{L}}$, $\mathrm{HE}_{\mathrm{DLM}} \mathrm{H}$, and $\mathrm{HE}-\mathrm{MHA}_{\mathrm{H}}$ groups were experimentally inoculated with $1 \mathrm{ml}$ of a suspension containing $\mathrm{HEV}$ at a dose of $10^{4,3}$ EID $_{50}$, administered into the crop with a probe [16]. In turn, turkeys from $0-\mathrm{DLM}_{\mathrm{L}}, 0-\mathrm{MHA}_{\mathrm{L}}, 0$ $\mathrm{DLM}_{\mathrm{H}}$, and $0-\mathrm{MHA}_{\mathrm{H}}$ group received $1 \mathrm{ml}$ of $\mathrm{PBS}$ via the same route.

\section{Sample collection}

Sample collection times and experiment design were presented in Table 7. All activities (vaccination, infection, sample collection) were performed between 7.00 and 8.00 a.m.
The immunological parameters were determined in blood, spleen and CTs. For this study, 7 turkeys at 47 days of life (representing average BW $\pm 10 \%$ per pen) were selected from each group, commonly accepted as the minimum number of turkeys with a unified genotype that ensures reliable, reproducible and statistically significant results without repeating the procedure due to high intra-group variability. Blood samples were collected from the wing vein into sterile test tubes (BD Vacutainer, USA) with the K2EDTA anticoagulant for flow cytometry or with lithium heparin for biochemical analysis. Selected birds from each group were euthanized and their spleen and CTs were collected for mononuclear cell isolation and determination of the percentages of $\mathrm{CD} 4^{+}$, $\mathrm{CD}^{+}, \mathrm{CD}^{+} \mathrm{CD}^{+}, \mathrm{CD} 4^{+} \mathrm{CD} 25^{+}, \mathrm{CD}^{+} \mathrm{IL}^{-} 6^{+} \mathrm{T}$ cell subpopulations and $\operatorname{IgM}^{+} \mathrm{B}$ cell subpopulation, by flow cytometry. Humanitarian euthanasia of the birds was performed with the use of a professional UNO Euthanasia Unit (UNOBV, Netherlands). The turkeys were placed in a chamber to which Carbogen $(95 \% \mathrm{O} 2+5 \% \mathrm{CO} 2)$ was provided by the unit. After $1 \mathrm{~min}$, Carbogen flow was stopped and $100 \% \mathrm{CO}_{2}$ was introduced into the cage. In this way, the high concentration of $\mathrm{O}_{2}$ was slowly replaced by $\mathrm{CO}_{2}$. This relatively slow replacement of $\mathrm{O}_{2}$ by $\mathrm{CO}_{2}$ is responsible for stress reduction in the birds.

At 56 days of age, all turkeys were weighed, and blood samples were collected from 23 birds per treatment into sterile test tubes without the anticoagulant for serological analysis.

\section{Isolation of mononuclear cells and flow cytometry}

Mononuclear cells from blood, spleen and CTs were isolated according to a previously described procedure $[17,39]$. The cells were counted, and their viability was evaluated using the Vi-Cell XR cell counter (Beckman Coulter, USA).

\section{Determination of the percentages of selected T cell and B} cell subpopulations in blood, spleen and CTs

Viable mononuclear cells $\left(1 \times 10^{6}\right)$ were stained with fluorescein conjugated Mouse Anti-Chicken CD4-FITC (MCA2164F, Bio-Rad, UK), phycoerythrin conjugated Mouse Anti-Chicken CD8a-RPE (MCA2166PE, Bio-Rad, UK) and Alexa Fluor 647 conjugated Human AntiChicken CD25 (HCA173A647, Bio-Rad, UK) or Alexa Fluor ${ }^{\odot} 647$ - conjugated Negative Control Antibody (HCA052A647, Bio-Rad, UK). B cells were stained separately with FITC-conjugated Goat Anti-Chicken IgM (AAI27F, Bio-Rad, UK). The percentages of $\mathrm{CD}^{+}$, $\mathrm{CD}^{+}{ }^{+} \mathrm{CD} 25^{+}, \mathrm{CD}^{+}, \mathrm{CD}^{+} \mathrm{CD}^{+}$and $\mathrm{IgM}^{+}$cells were determined in a FACSCanto II flow cytometer (BD, USA). Cell staining, acquisition and analysis of cytometric data were described elsewhere [18]. 


\section{Determination of the percentage of IL- 6 synthesizing cells within the $\mathrm{CD}^{+}$subpopulation}

Mononuclear cells isolated from blood, spleen and CTs were individually transferred at $2 \times 10^{6}$ to 24 -well plates (Corning, USA). Each well contained $2 \mathrm{ml}$ of complete culture medium (RPMI-1640, $20 \mathrm{mM}$ HEPES, 10\% FBS, Antibiotic Antimycotic Solution; Sigma-Aldrich, Germany), $4 \mu \mathrm{l}$ of Leukocyte Activation Cocktail with BD GolgiPlug ${ }^{\text {ma }}$ (BD Pharmingen, USA) and $0.3 \mu \mathrm{g} / \mathrm{ml}$ of co-stimulatory Mouse Anti-Chicken CD28 monoclonal antibody (MCA5760, clone AV7, Bio-Rad, UK). Cells collected from each turkey were analysed in triplicate. The cells were incubated at a temperature of $40^{\circ} \mathrm{C}\left(5 \% \mathrm{CO}_{2}\right)$ for $6 \mathrm{~h}$. After incubation, $20 \mu \mathrm{l}$ of $20 \mathrm{mM}$ EDTA solution (Sigma-Aldrich, Germany) in PBS was added to each well. The contents of each well were individually transferred to test-tubes, and were rinsed twice with PBS supplemented with 1\% FBS. The cells were stained with Mouse Anti-Chicken CD4-FITC monoclonal antibody (MCA2164F, clone 2-35, Biorad, UK). The samples were incubated on ice in darkness for $30 \mathrm{~min}$, and were rinsed with PBS. The cells were fixed with $100 \mu \mathrm{l}$ of Leucoperm reagent A (Biorad, UK), and were incubated at room temperature for $15 \mathrm{~min}$. After incubation they were washed with PBS at $300 \mathrm{~g}$ for $5 \mathrm{~min}$. Afterwards, they were suspended in $100 \mu \mathrm{l}$ of permeabilization medium (Reagent B, Leucoperm, Biorad, UK), and $5 \mu \mathrm{l}$ of Rabbit Anti-Chicken IL-6 antibody was added (AHP942Z, Biorad, UK). Thoroughly mixed samples were incubated at room temperature in darkness for $30 \mathrm{~min}$. After incubation, the cells were washed with PBS. The cells were suspended in $100 \mu \mathrm{l}$ of PBS, and $5 \mu \mathrm{l}$ of secondary antibodies Sheep Anti Rabbit IgG:PE (STAR35A, Bio-Rad, UK) was added. The samples were incubated at room temperature in darkness for 30 min. After incubation, the cells were washed with PBS. Final cell pellets were suspended in $400 \mu \mathrm{l}$ of PBS, and analysed with FACSCanto II flow cytometer (BD, USA).

A fluorescence minus one (FMO) control was prepared for each analysed sample. Primary Anti-Chicken IL-6 antibodies were not added to FMO controls. The cytometer setup and tracking beads (CST, BD, USA) were used to initialise photomultiplier tubes settings. Unstained and single-stained control cells for each fluorochrome were prepared and used to set up flow cytometry compensation.

\section{Biochemical and serological analyses}

Immediately after collection, blood samples were centrifuged ( $15 \mathrm{~min}, 380 \mathrm{~g}, 4^{\circ} \mathrm{C}$ ) and the obtained plasma or serum was stored at $-20^{\circ} \mathrm{C}$ until analysis. Plasma levels of IgA and IL- 6 were determined with the use of the Bigenet UMV340 blood cell reader (Horiba, Kyoto, Japan) and kits for determining IL-6 (SEA079Ga, Wuhan USCN Business Co., China) and IgA (CSB-E11232Ch, Cusabio Biotech Co., China).
Vaccine-induced titres of serum antibody against ORT and ND were determined with the use of commercial ELISA kits (Idexx Laboratories, USA). The analytical procedure was consistent with the manufacturer's recommendations. Absorbance was measured with the Elx 800 spectrophotometer (BioTek, USA). The results were analysed using the xChek 3.3 programme (Idexx Laboratories, USA).

\section{Statistical analysis}

The results were analysed statistically by three-way analysis of variance (ANOVA) using STATISTICA software version 12.0 (StatSoft Inc., USA). The significance of differences between means was determined by the F-test and Duncan's multiple range test. Data are presented as means \pm SEM and the value of $p<0.05$ was considered statistically significant. SEM was estimated by dividing the standard deviation by the square root of replication number.

\section{Abbreviations}

BSL-3: biosafety level-3; BW: Body weight; CD: Cluster of differentiation; CST: Cytometer setup and tracking beads; CTLA-4: Cytotoxic T-lymphocyte associated protein-4; CTs: Caecal tonsils; DLM: DL-methionine;

EDTA: Ethylenediaminetetraacetic acid; ELD 50 : Egg lethal dose; FMO: Fluorescence minus one; HE: Haemorrhagic enteritis;

HEV: Haemorrhagic enteritis virus; IFN: Interferon; IgA: Immunoglobulin A; IgM: Immunoglobulin M; IL: Interleukin; LAG-3: Lymphocyte activation protein 3; Met: Methionine; MHA: DL-methionine hydroxy analogue; NDV: Newcastle disease virus; ORT: Ornithobacterium rhinotracheale; p.i.: Post inoculation; SC: Secretory component; SEM: Standard error of the mean; $\mathrm{TCID}_{50}$ : Tissue culture infective dose; TGF- $\beta$ : Transforming growth factor- $\beta$; TNF: Tumour necrosis factor; $T_{\text {reg: }}$ : Regulatory $T$ cells

\section{Acknowledgements}

Not applicable.

\section{Authors' contributions}

BT and JJ conceived and designed the study. MS and BT collected the data. $\mathrm{KO}$ was involved in the chemical analysis. AK, BT, MS, KO, JJ and ZZ were involved in the data interpretation. BT, KO, MS and ZZ drafted the manuscript, and $A K, B T, J J, K O$ and $Z Z$ critically read and edited the manuscript. All authors read and approved the final manuscript.

\section{Funding}

This work was supported by the National Science Centre (grant No. 2013/11/ $\mathrm{B} / \mathrm{NZ9} / 02496)$. The funding body had no role in the design of this study and data analysis.

\section{Availability of data and materials}

The datasets generated and/or analysed during the current study are not publicly available due to restrictions in the contract with the funding body but are available from the corresponding author on reasonable request.

\section{Ethics approval and consent to participate}

The animal protocol used in this study was approved by the Local Ethics Committee (Olsztyn, Poland, License No. 45 of December 11, 2013) The study was carried out in accordance with EU Directive 2010/63/EU on the protection of animals used for scientific purposes.

Consent for publication

Not applicable.

Competing interests

The authors declare that they have no competing interests. 


\section{Author details}

'Department of Poultry Diseases, Faculty of Veterinary Medicine, University of Warmia and Mazury, Oczapowskiego 13, 10-719 Olsztyn, Poland. ${ }^{2}$ Department of Biochemistry and Toxicology, Faculty of Biology, Animal Sciences and Bioeconomy, University of Life Science in Lublin, Akademicka 13, 20-950 Lublin, Poland. ${ }^{3}$ Institute of Animal Reproduction and Food Research of the Polish Academy of Sciences, Division of Food Science, Tuwima 10, 10-748 Olsztyn, Poland. ${ }^{4}$ Department of Poultry Science, Faculty of Animal Bioengineering, University of Warmia and Mazury, Oczapowskiego 5, 10-719 Olsztyn, Poland.

\section{Received: 28 March 2019 Accepted: 13 October 2019}

Published online: 01 November 2019

\section{References}

1. Bunchasak C. Role of dietary methionine in poultry production. J Poult Sci. 2009:46:169-79.

2. British United Turkeys Ltd. http://eu.aviagen.com/ (2012).

3. Deng K, Wong CW, Nolan JV. Carry-over effects of early-life supplementary methionine on lymphoid organs and immune responses in egg-lying strain chickens. Anim Feed Sci Technol. 2007;134:66-76. https://doi.org/10.1016/j. anifeedsci.2006.05.008.

4. Dhama K, Tiwari R, Khan RU, Chakraborty S, Gopi M, Karthik K, Saminathan M, Desingu PA, Sunkara LT. Growth promoters and novel feed additives improving poultry production and health, bioactive principles and beneficial applications: the trends and advances -a review. Int J Pharmacol. 2014;10:129-59.

5. Dhama K, Gowthaman V, Karthik K, Tiwari R, Sachan S, Kumar MA, Palanivelu M, Malik YS, Singh RK, Munir M. Haemorrhagic enteritis of turkeys - current knowledge. Vet Q. 2017;37:31-42.

6. Garden OA, Pinheiro D, Cunningham F. All creatures great and small: regulatory $T$ cells in mice, humans, dogs and other domestic animal species. Int Immunopharmacol. 2011;11:576-88.

7. Gonzales-Esquerra R, Vázquez-Añón M, Hampton T, York T, Feine S, Wuelling $C$, Knight $C$. Evidence of a different dose response in turkeys when fed 2-hydroxy-4(methylthio) butanoic acid versus DL-methionine. Poult Sci. 2007:86:517-24.

8. Grimble RF, Grimble GK. Immunonutrition: role of sulfur amino acids, related amino acids, and polyamines. Nutrition. 1998;14:605-10.

9. Guiro S, Koncicki A. Vaccination against NDV in turkeys infected by haemorrhagic enteritis virus. Med Weter. 2004:60:871-3 http://www. medycynawet.edu.pl/images/stories/pdf/digital/2004/20040808710874.pdf.

10. Härtle S, Magor KE, Göbel TW, Davison F, Kaspers B. Structure and evolution of avian immunoglobulins. In: Schat KA, Kaspers B, Kaiser P, editors. Avian immunology. 2nd ed. London: Elsevier Academic Press; 2014. p. 103-20.

11. Hosseini SA, Zaghari M, Lotfollahian H, Shivazad M, Moraviaj H. Reevaluation of methionine requirement based on performance and immune responses in broiler breeder hens. J Poult Sci. 2012;49:26-33.

12. Jankowski J, Kubińska M, Zduńczyk Z. Nutritional and immunomodulatory function of methionine in poultry diets-a review. Ann Anim Sci. 2014;14:17-32. 10.

13. Jankowski J, Kubińska M, Juśkiewicz J, Czech A, Ognik K, Zduńczyk Z. Effect of different dietary methionine levels on the growth performance and tissue redox parameters of turkeys. Poult Sci. 2017;96:1235-43.

14. Jankowski J, Ognik K, Kubińska M, Czech A, Juśkiewicz J, Zduńczyk Z. The effect of DL-, L-isomers and DL-hydroxy analog administered at 2 levels as dietary sources of methionine on the metabolic and antioxidant parameters and growth performance of turkeys. Poult Sci. 2017;96:3229-38.

15. Kinscherf R, Fischbach T, Mihm S, Roth S, Hohenhaus-Sievert E, Weiss C, Edler L, Bärtsch P, Dröge W. Effect of glutathione depletion and oral Nacetyl-cysteine treatment on CD4 ${ }^{+}$and $C D 8^{+}$cells. FASEB J. 1994;8:448-51.

16. Koncicki A. Characteristics of domestic adenovirus isolates of haemorrhagic enteritis (HE) in turkeys and evaluation of epizootic situation in Poland. Acta Acad Agricult Tech Olst Veterinaria. 1996;22:1-43.

17. Koncicki A, Tykałowski B, Stenzel T, Śmiałek M, Pestka D. Effect of infection of turkeys with haemorrhagic enteritis adenovirus isolate on the selected parameters of cellular immunity and the course of colibacillosis. Pol J Vet Sci. 2012;5:215-20. https://doi.org/10.2478/v10181-011-0136-2.

18. Kubińska M, Tykałowski B, Jankowski J, Koncicki A. Immunological and biochemical indicators in turkeys fed diets with a different methionine content. Pol J Vet Sci. 2014;17:687-95.
19. Kubińska M, Tykałowski B, Koncicki A, Jankowski J. Biochemical and immunological responses of young turkeys to vaccination against Ornithobacterium rhinotraheale and different levels of dietary methionine. Pol J Vet Sci. 2015:18:807-16.

20. McGuirk P, Mills KH. Pathogen-specific regulatory T cells provoke a shift in the Th1/Th2 paradigm in immunity to infectious diseases. Trends Immunol. 2002;23:450-5.

21. Mills KH. Regulatory T cells: friend or foe in immunity to infection? Nat Rev Immunol. 2004:4:841-55.

22. Mirzaaghatabar F, Saki AA, Zamani P, Aliarabi H, Hemati Matin HR. Effect of different levels of diet methionine and metabolisable energy on broiler performance and immune system. Food Agr Immunol. 2011;22:93-103. https://doi.org/10.1080/09540105.2010.530249.

23. NRC: Nutrient requirements of poultry. $9^{\text {th }}$ rev. ed. Natl. Acad. Press, Washington, DC. 1994

24. Palya V, Nagy M, Glávits R, Ivanics E, Szalay D, Dán A, Süveges T, Markos B, Harrach B. Investigation of field outbreaks of Turkey haemorrhagic enteritis in Hungary. Acta Vet Hung. 2007;55:135-49.

25. Park I, Pasquetti TJ, Malheiros RD, Zheng L, Ferket P, Kim SW. Effect of grade L-methionine on intestinal redox status, intestinal development, and growth performance of turkey poults compared with conventional DL-methionine. J Anim Sci. 2016;94 Suppl 2:93. https://doi.org/10.2527/msasas2016-196.

26. Rautenschlein S, Sharma JM. Response of turkeys to simultaneous vaccination with hemorrhagic enteritis and Newcastle disease viruses. Avian Dis. 1999:43:286-92.

27. Rautenschlein S, Sharma JM. Immunopathogenesis of haemorrhagic enteritis virus (HEV) in turkeys. Dev Comp Immunol. 2000;24:237-46.

28. Rautenschlein S, Suresh M, Sharma JM. Pathogenic avian adenovirus type II induces apoptosis in Turkey spleen cells. Arch Virol. 2000;145:1671-83.

29. Rubin LL, Canal CW, Ribeiro AL, Kessler A, Silva I, Trevizan L, Viola T, Raber M, Goncalves TA, Kras R. Effects of methionine and arginine dietary levels on the immunity of broiler chickens submitted to immunological stimuli. Rev Bras Cienc Avic. 2007;9:241-7. https://doi.org/10.1590/S1516-635X2007000400006.

30. Scheller J, Chalaris A, Schmidt-Arras D, Rose-John S. The pro- and anti-inflammatory properties of the cytokine interleukin-6. Bochim Biophys Acta. 1813:2011:878-88.

31. Schneider K, Klaas R, Kaspers B, Staeheli P. Chicken interleukin-6 cDNA structure and biological properties. Eur J Biochem. 2001;268:4200-6.

32. Shanmugasundaram R, Selvaraj RK. Regulatory $T$ cell properties of chicken CD4 ${ }^{+}$CD25 $^{+}$cells. J Immunol. 2011;186:1997-2002.

33. Shanmugasundaram R, Selvaraj RK. Regulatory $T$ cell properties of thymic $\mathrm{CD}^{+}{ }^{+} \mathrm{CD} 25^{+}$cells in turkeys. Poult Sci. 2012;91:1833-7.

34. Smulikowska S, Rutkowski A. Recommended allowances and nutritive value of feedstuffs - poultry feeding standards. $5^{\text {th }}$ edition. The Kielanowski Institute of Animal Physiology and Nutrition, Jablonna, PAS Polish. 2005.

35. Suresh M, Sharma JM. Hemorrhagic enteritis virus induced changes in the lymphocyte subpopulations in turkeys and the effect of experimental immunodeficiency on viral pathogenesis. Vet Immunol Immunopathol. 1995:45:139-50.

36. Suresh M, Sharma JM. Pathogenesis of type II avian adenovirus infection in turkeys: in vivo immune cell tropism and tissue distribution of the virus. J Virol. 1996;70:30-6.

37. Swain BK, Johri TS. Effect of supplemental methionine, choline and their combinations on the performance and immune response of broilers. $\mathrm{Br}$ Poult Sci. 2000:41:83-8.

38. Swennen $Q$, Geraert PA, Mercier $Y$, Everaert N, Stinckens A, Willemsen $\mathrm{H}$, Li Y, Decuypere E, Buyse J. Effects of dietary protein content and 2-hydroxy-4-methylthiobutanoic acid or DL-methionine supplementation on performance and oxidative status of broiler chickens. Br J Nutr. 2011;106:845-1854.

39. Tykałowski B, Śmiałek M, Pestka D, Stenzel T, Jankowski J, Mikulski D, Koncicki A. Effect of whole wheat feeding on selected immune parameters in growing male turkeys. Pol J Vet Sci. 2014;17:255-62.

40. Tykałowski B, Koncicki A. Studies concerning the role of hemorrhagic enteritis virus in the pathology of turkeys conducted in the Department of Poultry Diseases in Olsztyn over the last 30 years. Med Weter. 2017;73:522-7 http://www. medycynawet.edu.pl/images/stories/pdf/pdf2017/092017/201709522527.ppd.

41. Vedenov D, Pesti GM. An economic analysis of a methionine source comparison response model. Poult Sci. 2010;89:2514-20.

42. Willemsen $H$, Swennen $Q$, Everaert N, Geraert PA, Mercier Y, Stinckens A Decuypere $\mathrm{E}$, Buyse J. Effects of dietary supplementation of methionine and 
its hydroxyl analog DL-2-hydroxy-4-methylthiobutanoic acid on growth performance, plasma hormonal levels, and the redox status of broiler chicken exposed to high temperatures. Poult Sci. 2011;90:2311-20.

43. Willke T. Methionine production - a critical review. Appl Microbiol Biotechnol. 2014;98:9893-921.

44. Wu B, Cui H, Peng X, Fang J, Cui W, Liu X. Effect of methionine deficiency on the thymus and the subsets and proliferation on peripheral blood T cell, and serum IL 2 in broilers. J Int Agri. 2012;11:1009-19.

45. Zduńczyk Z, Jankowski J, Kubińska M, Ognik K, Czech A, Juśkiewicz J. The effect of different dietary levels of DL-methionine and DL-methionine hydroxy analogue on the antioxidant and immune status of young Turkey. Arch Anim Nutr. 2017;71:347-61.

\section{Publisher's Note}

Springer Nature remains neutral with regard to jurisdictional claims in published maps and institutional affiliations.

Ready to submit your research? Choose BMC and benefit from:

- fast, convenient online submission

- thorough peer review by experienced researchers in your field

- rapid publication on acceptance

- support for research data, including large and complex data types

- gold Open Access which fosters wider collaboration and increased citations

- maximum visibility for your research: over $100 \mathrm{M}$ website views per year

At BMC, research is always in progress.

Learn more biomedcentral.com/submissions 